İş ve İnsan Dergisi | The Journal of Human and Work

Y1l | Year: Ekim | October 2020

Cilt-Sayı | Volume-Issue: 7 (2)

ss I pp: $339-349$

doi: $10.18394 /$ iid. 664138

e-ISSN 2148-967X

http://dergipark.gov.tr/iid/

\author{
Araştırma Makalesi
}

\title{
Türkiye'deki Bakanlıkların Misyon ve Vizyon İfadelerinin İçerik Analizi
}

\author{
Content Analysis of Mission and Vision Statements of Minıstries in Turkey
}

Selen Doğana, Ali Davut Alkan ${ }^{b}$

\section{MAKALE BİLGISI}

Anahtar Kelimeler:

Misyon, Vizyon, Stratejik

Planlama, Stratejik

Yönetim.,

Tarihler:

Geliş 24 Aralık 2019

Düzeltme geliş 19 Şubat

2020

Kabul 19 Şubat 2020

\section{A R T ICLE INFO}

\section{Keywords:}

Mission, Vision, Strategic

Planning, Strategic

Management.

Article history:

Received 24 December 2019

Received in revised form 19

February 2020

Accepted 19 February 2020

\section{ÖZ}

Türkiye'de 2016 yllından başlayarak kamu kurumlarında yașanan köklü değişikliklerle kamu kurumlarının yapıları ve stratejik planları da büyük değişime uğramıştır. Bu kapsamda, kamu kurumlarında stratejik yönetim sürecinin uygulanmasında misyon ve vizyon kavramları son derece önemli bir yere sahiptir. Kamu kurumlarının misyon ve vizyon ifadelerinin, ilgili kamu kurumunun teskilatlanmasın düzenleyen mevzuatla uyumlu olması beklenmekte ve gerekmektedir. Bu çerçevede araştırmada, 2019 Kasım ayı itibariyle Türkiye'de kamu hizmetlerini yürüten 16 Bakanlığın misyon ve vizyon ifadeleri içerik analizi yöntemiyle incelenmiş ve ilgili mevzuatla иуuти tespit edilmeye, misyon ve vizyon ifadelerinde en çok tekrarlanan kavramların tespitine çalıșılmıştır.

\begin{abstract}
A B S T R A C T
The structures and strategic plans of public institutions have undergone major changes with radical changes in public institutions starting from 2016 in Turkey. In this context, concepts of mission and vision are extremely important to implementation of strategic management process in public institutions. The mission and vision statements of public institutions are expected and necessity to be in line with legislation governing the organization of the relevant public institution. In this context, this research, sixteen Ministries', carrying out public services in Turkey, mission and vision statements were analyzed with content analysis method as of November 2019. And this article focused on identifying the content compliance with relevant legislation and the most repeated concepts in mission and vision statements.
\end{abstract}

\footnotetext{
a Prof. Dr., Niğde Ömer Halisdemir Üniversitesi, İktisadi ve İdari Bilimler Fakültesi, İşletme Bölümü, Niğde, Türkiye. E-mail: sdogan01@ohu.edu.tr. ORCID: 0000-0002-4019-5581

b Illetişim kurulacak yazar, Doktora Öğrencisi, Niğde Ömer Halisdemir Üniversitesi, İktisadi ve İdari Bilimler Fakültesi, İsletme Bölümü, Niğde, Türkiye. E-mail: alidavutalkan@ohu.edu.tr.ORCID: 0000-0002-9463-8683
} 


\section{GíRiş}

Eski çağlardan günümüze kadar geçen zamanla birlikte, başta insanoğlu olmak üzere, kamu ya da özel sektör işletmelerinde de pek çok teknik, yöntem, yap1, iş yapma tarzı, kısaca çok farklı unsurlar değişim sürecinden geçmiş ve değişimden kaçınılmaz olarak etkilenmiştir. Değişimin kaçınılmazlığı adeta tüm örgütlerin temel sorunu haline gelmiş, değişime ayak uyduramayan ve daha da önemlisi değişimi yönetemeyen işletmeler yok olma riski ile karşı karşıya kalmıştır. Bu değişim süreci salt bir alanda olmayıp; epistemolojik, siyasi, dini, ekonomik ve sosyolojik alanlarda gerçekleşmiş ve biri, bir diğerini etkileyerek gelişim göstermiştir. Her bir yenilik, kendisiyle ve etkilediği çevresiyle alakalı yeni düzenlemeleri de beraberinde getirmiştir. Genel olarak dünya ölçeğinde tarihsel süreçte ortaya çıkan birçok yeni olgu, Türkiye özelinde de benzer bir seyir izlemiştir. Tanrısal bilgi biçimlerinden bilimsel biçimlere geçiş, yeni siyasi örgütlenme şekilleri, kapitalizmin yayılması ve yeni toplumsal sınıfların ortaya çıkışı vb. değişimler, yeni kavramların ve anlayışların oluşumunu sağlamıştır. Bahsi geçen değişimlerin bu çalışma bağlamındaki yansıması ise yönetim anlayışındaki değişme ve gelişmelerdir. Batı'da yönetim anlayışındaki değişimin, Sanayi Devrimi'yle birlikte ivmelenmesiyle ortaya çıkan yeni kavramların diğer toplumlarca transferi de hız kazanmıştır. Türkiye'nin de benzer biçimde Cumhuriyet'le birlikte yönetim algısı yön değiştirmeye başlamıştır. Bu değişim süreci sürekli devam eden, kendini geliştirmeye çalışan ve yapısal değişimleri beraberinde getiren dinamik bir süreç olarak karşımıza çıkmaktadır. İşte bu noktada, değişimin pratik yansıması olarak yönetsel bir dönüşüm süreci bağlamında, yürütme işlevinin büyük bölümünü merkez ve taşra teşkilatlarıyla idame ettiren Bakanlıklarda da köklü değişimler yaşanmıştır. Örgütsel değişimin başarısı için stratejik planlama yapmak tek başına yeterli olmamakla birlikte neredeyse tüm kamu ve özel sektör işletmeleri için adeta ilk ve zorunlu bir unsur olarak karşımıza çıkmaktadır. Stratejik planlama mantığının kurumlarda yerleştirilmeye çalışılmasıyla birlikte de vizyon ve misyon kavramları, bunların kurumlar için ifade ettiği anlam da tartışılmaya başlanmıştır.

Türkiye'de, 15 Temmuz 2016 hain darbe girişimi sonrasında birçok kamu kurumun yapısı değiştirilmiş, kamuda görev yapan personelden terör örgütüyle iltisaklı olanlar ihraç edilmiş ve köklü bir takım düzenlemeler yapılmıştır. $\mathrm{Bu}$ kapsamda, yürütme işlevinin büyük bölümünü merkez ve taşra teşkilatlarıyla idame ettiren Bakanlıklarda da köklü değişimler yaşanmıştır.

Türkiye bu değişim süreciyle birlikte yürütme organlarından olan Bakanlıkların oluşturulması, sonlandırılması, görev ve yetkilerinin belirlenmesi, örgütlenme yapısı ile merkez ve taşra teşkilatlarının kurulmasını Cumhurbaşkanlığı Kararnamesi ile gerçekleştirmeye başlamıştır. Zira Bakanlıkların kurulması ve aktüel teşkilat yapısı, Cumhurbaşkanlığının örgütlenme biçimi ve Bakanlıklara bağlı ve ilişkili kuruluşların düzenlenmesi Cumhurbaşkanlığı Kararnameleriyle olmuştur (Turan, 2018: 59).

Anayasamızın 21 Ocak 2017 tarihli ve 6771 sayılı Kanun'la değişik 106'ncı maddesinin 11'inci fikrasında, "Bakanlıkların kurulması, kaldırılması, görevleri ve yetkileri, teşkilat yapısı ile merkez ve taşra teşkilatlarının kurulması Cumhurbaşkanlığı Kararnamesi'yle düzenlenir" denilmektedir. Söz konusu hususlar, 10 Temmuz 2018 tarihli Resmî Gazete'de yayınlanan 1 numaralı Cumhurbaşkanlığ Teşkilatı Hakkında Cumhurbaşkanlığı Kararnamesi ile düzenlenmiştir. Kararnamenin 38 ile 524'üncü maddeleri arasında yer alan toplam 486 maddesinde çeşitli Bakanlıkların kuruluşları, görevleri ve yetkileri, merkez ve taşra teşkilatları düzenlenmiştir (Gözler \& Kaplan, 2018: 62).

Yeni sistemde oluşturulan Bakanlıklar alfabetik sıraya göre Tablo 1'de belirtilmiştir.

9 Temmuz 2018 tarihinden sonra, yani yeni hükümet sisteminde Bakanlar, doğrudan doğruya Cumhurbaşkanı tarafindan atanan ve görevden alınan, TBMM'ye karşı değil Cumhurbaşkanına karş1 sorumlu olan idari görevlilerdir. Hükümetin üyesi değildirler. Cumhurbaşkanı yürütme yetkisine bütünüyle sahiptir diğer bir ifadeyle Bakanlıklar yürütmenin yetki olarak bir parçasına sahip değildirler (Gözler \& Kaplan, 2018: 61).

10 Temmuz 2018 tarihli ve 1 say1l Cumhurbaşkanlığı Kararnamesi'nin 503'üncü maddesinin 2'nci fikrasında şöyle denilmektedir; "Bakanlar, kamu kaynaklarının etkili, ekonomik ve verimli kullanımı amacıyla, bakanlık hizmetlerini mevzuata, Cumhurbaşkanının genel siyasetine, Cumhurbaşkanı karar ve talimatlarına, kalkınma planlarına ve yıllık programlara uygun olarak yürütmekle, bakanlığın faaliyet alanına giren konularda diğer bakanlıklarla işbirliği ve koordinasyonu sağlamakla görevli ve Cumhurbaşkanına karşı sorumludur" (Gözler \& Kaplan, 2018: 63-64).

Bakanlıkların, merkez ve taşra teşkilatları aracılığ ile kamu hizmetleri sunmakla görevli olmaları ve bu 
Tablo 1: Yeni Sisteme Göre Oluşturulan Bakanlıklar

\begin{tabular}{|c|c|c|c|}
\hline NO & BAKANLIK ADI & NO & BAKANLIK ADI \\
\hline 1 & Adalet Bakanlığ & 9 & Kültür ve Turizm Bakanlığı \\
\hline 2 & $\begin{array}{l}\text { Aile, Çalışma ve Sosyal Hizmetler } \\
\text { Bakanlığı }\end{array}$ & 10 & Millî Eğitim Bakanlığı \\
\hline 3 & Çevre ve Şehircilik Bakanlığı & 11 & Millî Savunma Bakanlığı \\
\hline 4 & Dışişleri Bakanlığı & 12 & Sağlık Bakanlığ \\
\hline 5 & Enerji ve Tabii Kaynaklar Bakanlığı & 13 & Sanayi ve Teknoloji Bakanlığı \\
\hline 6 & Gençlik ve Spor Bakanlığı & 14 & Tarım ve Orman Bakanlığı \\
\hline 7 & Hazine ve Maliye Bakanlığı & 15 & Ticaret Bakanlığ \\
\hline 8 & İçişleri Bakanlığ1 & 16 & Ulaştırma ve Altyapı Bakanlığı \\
\hline
\end{tabular}

durumun algilanan kamu hizmetinin kalitesini belirleyici niteliği, Kamu kurumlarının sundukları hizmetlerin kamu mevzuatına ve Cumhurbaşkanının genel siyasetine uyumlu olması gerekliliği, artık kamu kurumlarının da sundukları hizmetin kalitesinin ölçülmesine ihtiyaç duyulması ve bazı kamu kurumlarının hizmeti alan vatandaşlardan farklı kanallarla geri bildirim istemeleri kamu hizmetlerinin belirli standartlara göre verilmesinin önemini artırmıştır. Yürütme organının tüm birimlerinin misyon ve vizyon ifadelerinin Cumhurbaşkanlığı ile uyumlu olması gerekliliği önem kazanmıştır.

Tüm bu nedenlerle bu çalışmada; Bakanlıkların misyon ve vizyon ifadeleri ile kuruldukları kararnamede kendilerine atfedilen görevler arasında bir eşgüdüm olup olmadığını tespit etmek amacıyla bazıları yeni kurulmuş, bazıları eski ismiyle görevine devam eden Bakanlıkların misyon ve vizyon ifadelerinin içerik analizi yapılmıştır. Aşağıda öncelikle stratejik yönetim sürecine ve bu süreçte önemli bir yer tutan misyon ve vizyon kavramlarına değinilmiş, misyon ve vizyon ifadelerinin stratejik yönetim süreci ve kurum için önemine atıfta bulunulmuş, içerik analizine ilişkin bulgular paylaşılmış ve son olarak çözüm önerileri ile gelecek çalışmalara ilişkin önerilere yer verilmiştir.

\section{MISYON ve VIZZYON KAVRAMLARININ STRATEJIK YÖNETIM SÜRECINDEKİ YERİ ve ÖNEMİ}

Büyük ya da küçük, kâr amaçlı ya da değil, kamusal ya da özel bütün kurumlar, hızla küreselleşmekte olan, artan düzeyde rekabetçi bir ortamda bulunmaktadırlar (Quigley, 1998: 278). Türkiye'de de dünyadaki diğer benzer kurumlarda olduğu üzere büyük ölçekli iktisadi kurumlar benzer amaç ve önceliklere sahip görünmektedir (Ay \& Koca, 2012: 209). Misyon, vizyon ve stratejik amaçlar konusunda akademik camia ziyadesiyle özel sektör ve kuruluşlarına odaklanmış (Kunt, 2012: 95) gözükse de kamu kurumları için de son derece önemli olduğu bugün herkesçe kabul edilmektedir. Örgütler büyüdükçe kişisel olmaktan çıkmakta ve kamuya ait bir örgüt olsa da giderek artan bir biçimde anlamını yitirmek tehlikesi ile karşılaşmaktadırlar (Acar, 2003: 5).

Vizyon kelimesi Latince "videre" kökünden gelmektedir ve görmek anlamında kullanılmaktadır. Geniş bir perspektiften bakıldığında, vizyon “bilmek”tir. Çünkü insan gördüğünü bilebilir (Doğan, 2007: 102). İyi bir vizyon beyanının bir döneme ilişkin gelecekteki en az beş, tercihen on yılı içermesi gerektiği, anlaşılabilir, özlü ve mümkünse bir cümleden oluşması gerektiği vurgulanmıştır. Bir organizasyonun vizyonu yazılı hale getirilerek ilgili herkese ayrıntıları ile açıklandığında ve sürekliliği olan bir amacı temsil ettiğinde çalışanların vizyona bağl1lıkları artmaktadır (Taş, Çiçek \& Yastıoğlu, 2019: 549).

Stratejik yönetim süreci; işletmenin uzun dönemde yaşamını devam ettirmesine ve sürdürebilir rekabet üstünlüğü sağlamasına yönelik bilgi toplama, analiz, seçim, karar ve uygulama faaliyetlerinin tümüdür. Stratejik yönetim sürecinin ilk aşaması stratejik bilincin oluşturulmasıdır. $\mathrm{Bu}$ aşamayı sırasıyla; stratejistlerin seçimi ve görevlendirilmesi, stratejik analiz, stratejik yönlendirme, strateji oluşturma, strateji uygulama ve stratejik kontrol aşamaları takip etmektedir (Ülgen \& Mirze, 2018: 44-45).

Stratejik yönetim sürecinde, misyon ve vizyon ifadelerinin belirlendiği aşama stratejik yönlendirme aşamasıdır (Ülgen \& Mirze, 2018: 45). Başka bir deyişle, misyon ve vizyon ifadelerinin doğru belirlenememesi; stratejik yönlendirme aşamasının, bu aşamanın ardılı olarak strateji oluşturma aşamasının ve bir bütün olarak stratejik yönetim sürecinin sekteye uğramasına sebep 
olabilmektedir. $\mathrm{Bu}$ nedenle, misyon ve vizyon ifadelerinin uygun şekilde belirlenmesi, kurumların stratejik yönetim süreçlerini sağlıklı sürdürebilmeleri açısından son derece önemlidir. Hatta misyon ve vizyon ifadeleri uygun şekilde belirlenmediği takdirde, kurumların strateji oluşturma aşamasına geçemeyeceği ve bir stratejik yönetim sürecinin ilgili kurumda uygulanamayacağ sonucu bile çıkarılabilmektedir.

Devletin, hükümetin ve onun kurumlarının ortak değerlere ve vizyona özel sektöre oranla daha az ihtiyaç duyması gibi bir durum söz konusu olamaz. Büyük ölçekli hükümet ve kamu kurumlarında görev alan bir çalışanın zamanla görev tanımı anlamını yitirmektedir. Fakat bununla birlikte, anlam arayışı daima sürer ve teşebbüsün sahip olduğu vizyon bu anlamı sağlamalıdır. Devlet için çalışan birinin maddi doyumu daha az olabileceğinden vizyon daha da sağlam ve etkin olmalıdır. Bu kurumlar, daha önce Japon şirketleri örneğinde olduğu üzere insanlara daha fazla değer vermelidirler (Quigley, 1998: 34).

Türkiye'de kamu yönetiminin sorunları, nüfusun artmas1, kamu hizmeti sunulacak kesimin genişlemesi ve değişmesi, iletişimin artmasıyla beraber kamu hizmetlerinin kıyaslanması, teknolojinin sürekli gelişmesi, vatandaşın devletten beklentilerinin artması ve devlete yeni görevler yüklenmesi gibi nedenlerle sürekli artış göstermiştir (Erdem, 2006: 92).

Her ne kadar piyasada faaliyet gösteren birçok kurumun stratejik plan hazırladığ ifadeleri belirlediği bilinen bir gerçek olsa da kamu kurumlarının vizyonları şekillendirilirken ele alınacak unsurlar, özel sektörden farklılaşmaktadır. Bir kamu kurumunun vizyonu, idealisttir ve anlam yüklenerek benimsenmelidir. Özgündür ve kuruluşun değerlerini diğerlerinden ayırt edicidir. Çekicidir; yani kuruluş kadar dış paydaşlarının da ilgi konusu olmaktadır (Taş vd., 2019: 549). Günümüz dünyasında çoğu ülkede kamu yönetimleri ürettikleri mal ve hizmetlerde kaliteyi, verimliliği, etkinliği ve hakkaniyeti en öndeki hedefler olarak görmektedirler (Erçelik, 2014: 138). Açıkça tanımlanmış bir vizyon olmaksızın işletmeler çevreleri ve taklitçi rakiplerle uğraşma riski ile karşı karşıya gelecekler, güçlükler ve yanlışlıklar içinde sürüklenip gideceklerdir (Doğan, 2007: 107). Vizyon bildirilerinin en can alic1 noktasını misyon oluşturmaktadır (a.g.e: 132). Misyon, kelime anlamı olarak bir kişi veya topluluğun üstlendiği özel görev demektir (a.g.e: 123).

Misyon kurumların varlık nedenlerini veya kendilerini nasıl gördüklerini ifade etmek için kullanılmaktadır. Misyon kurumun uzun dönemli amacıdır. Kurumun varlığı devam ettikçe misyonu da değişmez (Erçelik, 2014: 127). Misyon, vizyon ve amaç ifadeleri sadece stratejik planlarda, internet sayfasında ve el kitaplarında yer alan süslü kelimeler öbeği değildir. Bu ifadeleri üniversite duvarlarına asarak bir mucizenin gerçekleşmesini beklemek de doğru olmayacaktır. Bu yüzden misyon, vizyon ve amaçların uygulamaya aktarılması büyük önem arz etmektedir (Taş vd., 2019: 559).

Stratejik yönetimin kamu kurumlarında uygulanmasında dikkat edilmesi gereken önemli bir husus; özel sektör kârını artırmayı ve parası olan müşterileri tatmin etmeyi hedeflerken, kamu sektöründe vatandaş refahı, eşitlik, hakkaniyet, adalet ve kamu yararı gibi kamu değerlerinin dikkate alınarak eşit hak ve görevlere sahip vatandaşların gereksinimlerinin karşılanması zorunluluğunun olduğudur (Uçar, 2010: 184).

Bugün, etkili, verimli ve başarılı olmak isteyen işletmeler/kurumlar için amaçlarda, politikalarda, programlarda ve diğer tüm alanlarda dikkate alınması gereken en önemli faktör stratejik yönetimdir (Acar, 2003: 12). Misyon ve vizyon ifadelerinin genel politikalar ile uyumlu olup olmadığı özellikle kamu kurumlarında büyük önem arz etmektedir. Bu çerçevede kamu kurumlarının stratejik planlarının uygulanabilir olması, amaca uygun belirlenmiş misyon ve vizyon kavramlarına bağlıdır denilebilir.

\section{YÖNTEM VE UYGULAMA}

$\mathrm{Bu}$ çalışmada nitel araştırma yöntemi tercih edilmiştir. Nitel araştırmalarda başlica veri toplama tekniği; gözlem, mülakat, dokümanlar ve anketlerdir. Elde edilen bu tür veriler, tümevarım yaklaşımıyla analiz edilerek betimsel olarak raporlanmaktadır (Gürbüz \& Şahin, 2018: 103). Nitel araştırma görüşme, gözlem, doküman analizi gibi nitel veri toplama tekniklerinin kullanıldığı, olayların ve algıların doğal ortamda gerçekçi ve bütüncül bir şekilde ortaya konmasına yönelik nitel bir sürecin izlendiği araştırmadır (Yıldırım \& Şimşek, 2006: 39).

Araştırmada veri toplama tekniği olarak belge (doküman) incelemesi kullanılmıştır. Doküman incelemesi, araştırılması hedeflenen olgu ve olgular hakkında bilgi içeren yazılı materyallerin analizini kapsamaktadır (Yıldırım \& Şimşek, 2006: 187). Doküman incelemesinde, çeşitli analiz birimleri araştırmanın amacına göre farklılık göstermektedir; karakter, sözcük, cümle, tema veya paragraf, içerik 
ve madde. Bir belgedeki en temel birim genellikle en küçük birimdir. $\mathrm{Bu}$ anlamda kelimeler bir belgenin en basit birimleridir ve doküman analizine konu olabilirler. Sözcüklerin analiz birimi olarak kullanılması bazı kolaylıklar da sağlar; çünkü bağımsız ve sonludurlar, sınırları açık-seçik bellidir ve tanınmaları oldukça kolaydır (Yıldırım \& Şimşek, 2006: 199).

Elde edilen verilerin analizinde içerik analizi yöntemi kullanılmıştır. İçerik analizi; dokümanların, mülakat dökümlerinin ya da kayıtlarının karakterize edilmesi ve karşılaştırılması için kullanılan bir tekniktir (Altunışık, Coşkun, Bayraktaroğlu \& Yıldırım, 2012: 324). İçerik analizinde, önceden belirlenmiş kriterlere göre belirli sayıda yazılı, görsel veya işitsel materyal incelemeye tabi tutularak bazı temalar yakalanmaya çalış1lmaktadır (Nakip \& Yaraş, 2017: 147). Burada içerik analizinin temel amacı, toplanan verileri anlamlandırabilecek ilişkilere ve kavramlara ulaşmaktır. Yapılan işlem asıl olarak içerik analizinde, birbirine benzeyen verileri belirli kavramlar ve ilişkiler bağlamında bir araya getirmek ve bunları araștırmayı inceleyenlerin anlayabileceği bir şekilde düzenleyerek yorumlamaktır (Yıldırım \& Şimşek, 2006: 227).

Doğru bilgiye ulaşma konusunda gerekli önlemlerin alınması (yani geçerlilik) ve araştırma sürecini ve bilgileri açık ve ayrıntılı bir şekilde, yani başka araştırmacıların değerlendirmesine olanak verecek biçimde tanımlanması (yani güvenirlik), nitel araştırmacıların karşılaması gereken önemli beklentilerdir (Yıldırım \& Şimşek, 2006: 274). Özetle, araştırmanın amacına uygun olarak, bu araştırmada nitel araştırma yöntemlerinden doküman incelemesi ve içerik analizi kullanılmıştır. Elde edilen veriler yorumlanarak bulgular kısmında değerlendirilmiş ve bazı öneriler getirilmiştir.

Araştırma kapsamında, Türkiye'de Kasım 2019 tarihi itibariyle faaliyet gösteren 16 Bakanlığın misyon ve vizyon ifadelerine ilgili Bakanlıkların web siteleri üzerinden ulaşılmış, söz konusu ifadelerde en çok tekrarlanan kavramlar misyon ve vizyon ifadeleri için ayrı ayrı çizelgelerde toplanarak bu kavramların sayımı yapılmıştır. Daha sonra bu kavramlar Bakanlıkların kuruluşuna esas teşkil eden, 10 Temmuz 2018 tarihli ve 1 sayılı Cumhurbaşkanlığı Kararnamesinin 503'üncü maddesinde yer alan kavramlarla karşılaştırılmıştır. Özetle, çalışmada nitel araştırma tekniklerinden doküman incelemesi yöntemi tercih edilmiştir. Daha önce değinildiği üzere doküman incelemesi yapılırken; karakter, sözcük, cümle, tema, içerik ve madde unsurlarına yoğunlaşılmıştır. Elde edilen verilerin anlamlandırılmasında içerik analizi yöntemi kullanılmıştır. Sıklık analizleri herhangi bir veri analizi programı kullanılmadan sayma yöntemiyle yapılmıştır. Bu kavramların hangilerinin en çok kullanıldığ 1 , hangilerinin ilgili mevzuattaki kavramlarla benzeştiği tespit edilmiştir.

\subsection{Araştırmanın Amacı}

Araştırmanın amacı; Türkiye'de Kasım 2019 tarihi itibariyle faaliyet gösteren Bakanlıkların misyon ve vizyon ifadelerinde geçen kavramların sıklıkları ve bu kavramların Bakanlıkların kuruluşuna esas teşkil eden Cumhurbaşkanlığı Kararnamesi ile uyumlarını tespit etmektir.

Araştırma, amacı bakımından keşfedici bir araştırmadır. Keşfedici araştırmalarda genellikle nitel araştırma teknikleri kullanılır. Keşfedici araştırma, bir yazın taraması, konuyla ilgili uzmanlarla mülakat, odak grup mülakatı gibi farklı yollarla yapılabilmektedir (Gürbüz \& Şahin, 2018: 101).

\section{2. Örneklem ve Veri Toplama Süreci}

Araştırmanın örneklemini, Kasım 2019 tarihi itibariyle Türkiye'deki $16 \quad$ Bakanlık oluşturmaktadır. Araştırma kapsamında, Bakanlıklara ait misyon ve vizyon ifadelerine ilgili Bakanlıkların web sitelerinden ulaşılmış olup bu kaynaklar internet üzerinden herkesin erișebileceği açık kaynaklardır.

Adalet, Aile, Çalışma ve Sosyal Hizmetler, Çevre ve Şehircilik, Enerji ve Tabii Kaynaklar, İçişleri, Kültür ve Turizm, Millî Eğitim, Millî Savunma ve Sağlık Bakanlıkları olmak üzere 9 Bakanlığın misyon ve vizyon ifadelerine web sayfaları üzerinden doğrudan ulaşılmıştır.

Hazine ve Maliye, Sanayi ve Teknoloji, Tarım ve Orman, Ticaret Bakanlıkları olmak üzere 4 Bakanlığın misyon ve vizyon ifadelerine, ilgili Bakanlıkların 2018-2022; Dışişleri ile Ulaştırma ve Altyap1 Bakanlıklarının misyon ve vizyon ifadelerine ise ilgili Bakanlıkların 2019-2023 Stratejik Planlarının içeriği incelenerek ulaşılabilmiştir.

Gençlik ve Spor Bakanlığının misyon ve vizyon ifadelerine web sayfasında rastlanmamıştır. Bakanlığın web sitesinde, Bakanlığa ait 2018-2022 veya 2019-2023 Stratejik Planına da rastlanmamıştır. İlgili Bakanlığın Strateji Geliştirme Başkanlığ 1 01.11.2019 tarihinde telefonla aranmıştır. Yapılan telefon görüşmesinden Bakanlığın misyon ve vizyon ifadelerinin hazırlanarak onay için Cumhurbaşkanlığına gönderildiği öğrenilmiştir. Daha sonra ilgili Bakanlığın web sitesi üzerinden bakanlık-stratejik 
yönetim-dosyalar sekmeleri takip edilerek ilgili Bakanlığın 2018 Faaliyet Raporuna erişilmiş ve bu dosyanın içinde misyon ve vizyon ifadelerine ulaş1labilmiştir.

Nitel veri analizi genel olarak tümevarımcı bir yaklaşımla gerçekliği ortaya çıkarmaya ve anlamaya çalışmaktadır (Gürbüz \& Şahin, 2018: 436). Tümevarımcı analiz; verilerin temelinde yer alan kavramları ve bu kavramlarının diğerleriyle olan ilişkilerinin ortaya konmasıdır (Yıldırım \& Şimşek, 2006: 227). Kavram; elde edilen verilerle anlamlı bölümlere(bir sözcük, cümle, paragraf gibi) ve vakalara verilen tanımdır. Kavramlar, içerik analizinde temel analiz birimini oluşturmaktadır (a.g.e: 228).

Belgelerden elde edilen verilerin sayısallaştırılmasıyla ilgili karar tamamen araştırmacılara aittir. Sonuçlar, düzyazı şeklinde raporlanabileceği gibi çeşitli verilerin nicelleştirilmesi de tercih edilebilir (Saruhan \& Özdemirci, 2011: 240). Nitel araştırmalarda verilerin analizinin standart hale getirilemeyeceği açıktır. Bu, nitel araştırmanın felsefesine aykırıdır. Araştırma sonuçları kapsamlı ve sistematik şekilde analiz edilmelidir, ancak her araştırma için geçerli olacak bir yöntem yoktur (a.g.e: 271 ).

Nitel yaklaşım, her araştırmacının olayları algılama ve yorumlama biçimin farklı olabileceğini kabul etmektedir. Aynı verileri iki farklı araştırmacının farklı algılaması ve yorumlaması kaçınılmaz olabilir ve olağandır (Yıldırım \& Şimşek, 2006: 259). Nicel yaklaşımda çalışma öncesinde bir plan oluşturulurken nitel yaklaşımda önceden belirlenmiş adımlara kesin şekilde uyulması gerekliliği yoktur. Bunun yerine takip edilmesi gereken genel ilkeler söz konusudur (Gliner, Morgan \& Leech, 2015:7).

Araştırmacılar, toplanan verileri işlenmiş hale getirmekte ve okuyucuya sunmaktadır. Araştırmacılar bu aşamada, nitel verileri sayısal hale getirmeyi tercih edebilmektedir. Basit yüzde hesapları ya da kelime sıklık hesapları, bu alanda en sık kullanılan iki yöntemdir. Araştırmacı son olarak alıntılara ve içerik analizlerine kendi yorumlarını da eklemektedir. Burada elde edilen sonuçların ne anlama geldiği öznel bir perspektiften ele alınmaktadır (Saruhan \& Özdemirci, 2011: 273).

\section{BULGULAR}

10 Temmuz 2018 tarihli ve 1 sayılı Cumhurbaşkanlığı Kararnamesi'nin 503'üncü maddesinin 2'nci fikrasında, Bakanlıkların kamu kaynaklarını "etkili", "ekonomik" ve "verimli" kullanmaları gerekliliği belirtildiğinden Bakanlıkların misyon ve vizyon ifadelerinde öncelikle bu kavramlar aranmıştır.

Zira ilgili fikrada, Bakanların görevlerini nasıl yürüteceklerine değinilmiş olup fikra içerisinde misyon ve vizyon ifadelerinde yer alabilecek bu üç kavram öne çıkmaktadır. Söz konusu kavramlar, Bakanların çalışma şekillerini belirleyen ilgili mevzuat içeriğinde misyon ve vizyon ifadelerinde yer alabilecek olan "etkili", "ekonomik" ve "verimli" kavramları olarak belirlenmiştir. İlgili mevzuatın içeriği incelendiğinde bu üç kavram haricindeki kavramlar genel işleyişe yönelik kavramlar olarak değerlendirilebilir. Bahsi geçen pratik kaygıların yanı sıra teorik açıdan stratejik yönetim sürecinin doğru işleyebilmesi adına stratejik yönlendirme aşamasında misyon ve vizyon ifadelerine odaklanma zorunluluğu ortaya çıkmıştır.

Ancak bu kavramlar dışında Bakanlıkların misyon ve vizyon ifadelerinin içerik analizi yapıldığında aşağıdaki kavramların da kullanıldığına rastlanmıştır. Bu kavramlar Tablo 2'de alfabetik olarak sıralanmıştır (bkz. Tablo 2

Her kavramın hem misyon hem de vizyon ifadelerinin içinde geçip geçmediği, geçtiyse kaç defa geçtiği tespit edilmiştir. Söz konusu kavramların vizyon ifadelerinde kullanım sıklığ Tablo 3'te, misyon ifadelerinde kullanım sıklığ Tablo 4'te sunulmuştur (bkz. Tablo 3-4).

Vizyon ifadeleri incelendiğinde; 10 Temmuz 2018 tarihli ve 1 sayılı Cumhurbaşkanlığ Kararnamesi'nin 503'üncü maddesinin 2'nci fikrasında, Bakanlıkların kamu kaynaklarını "etkili", "ekonomik" ve "verimli" kullanmaları gerekliliği vurgulanmasına rağmen bu ifadelere rastlanmamıştır.

Vizyon ifadelerinde; en çok tekrarlanan kavramlar olarak, "Güçlülük” 5 kez, "Güvenli” 4 kez, "Öncülük" 3 kez ve "Erişilebilirlik" 3 kez Bakanlıkların vizyon ifadelerinde yer almıştır. Benzer şekilde bütün Bakanlıkların vizyon ifadelerinde tamamı birbirinden farklı olmak üzere, 8 kavram 1'er kez, 5 kavram 2'şer kez kullanılmıştır.

Türkiye'deki 16 Bakanlığın misyon ve vizyon ifadeleri incelendiğinde, 10 Temmuz 2018 tarihli ve 1 sayılı Cumhurbaşkanlığg Kararnamesi'nin 503'üncü maddesinin 2'nci fikrasında, Bakanlıkların kamu kaynaklarını "etkili", "ekonomik" ve "verimli" kullanmaları gerekliliği vurgulanmıştır. Ancak; "Etkililik" kavramının 3, "Ekonomik" kavramının 2 ve "Verimlilik" 
Tablo 2: Bakanlıkların Vizyon ve Misyon İfadelerinde Kullanılan Bazı Kavramlar

\begin{tabular}{clcl}
\hline NO & Kullanılan Kavram & NO & Kullanılan Kavram \\
\hline $\mathbf{1}$ & Çevreye Duyarlılık & $\mathbf{1 4}$ & Katılımcıllı \\
$\mathbf{2}$ & Çözüm Odaklılık & $\mathbf{1 5}$ & Küresellik \\
$\mathbf{3}$ & Denetleyicilik & $\mathbf{1 6}$ & Liderlik \\
$\mathbf{4}$ & Düzenleyicilik & $\mathbf{1 7}$ & Millilik \\
$\mathbf{5}$ & Ekonomiklik & $\mathbf{1 8}$ & Öncülük \\
$\mathbf{6}$ & Erişilebilirlik & $\mathbf{1 9}$ & Rekabetçilik \\
$\mathbf{7}$ & Etkililik & $\mathbf{2 0}$ & Saygınlık \\
$\mathbf{8}$ & Etkinlik & $\mathbf{2 1}$ & Sürdürülebilirlik \\
$\mathbf{9}$ & Evrensellik & $\mathbf{2 2}$ & Süreklilik \\
$\mathbf{1 0}$ & Girişimcilik & $\mathbf{2 3}$ & Üretkenlik \\
$\mathbf{1 1}$ & Güçülük & $\mathbf{2 4}$ & Verimlilik \\
$\mathbf{1 2}$ & Güvenli & $\mathbf{2 5}$ & Yenilikçilik \\
$\mathbf{1 3}$ & Kalkınmacılık & & \\
\hline
\end{tabular}

kavramının sadece 1 Bakanlığın misyon ifadelerinde yer aldığı gözlemlenmiştir.

Diğer kavramlar arasında ise "Sürdürülebilirlik" kavramı öne çıkmakta ve 7 Bakanlığın misyon ifadesinde yer almaktadır. "Yenilikçilik" 5, "Kalkınmacılık" 4, "Etkinlik" 4 ve "Katılımcılık" 3 Bakanlığın misyon ifadelerinde yer almıştır.

Bakanlıkların faaliyet alanları farklı olsa da her alanda kullanılabilecek geniş anlama sahip bazı genel kavramları kullanmada farklı yaklaşım sergiledikleri Tablo 3 ve Tablo 4 incelendiğinde görülmektedir. Zira bütün Bakanlıkların misyon ifadelerinde tamamı birbirinden farklı olmak üzere, 6 kavram birer kez, 8 kavram ikişer kez kullanılmıştır.

Ayrıca; 10 Temmuz 2018 tarihli ve 1 sayılı Cumhurbaşkanlığı Kararnamesi'nin 503'üncü maddesinin 2'nci fikrasında belirtilen "Bakanlar, kamu kaynaklarının etkili, ekonomik ve verimli kullanımı amacıyla, bakanlık hizmetlerini mevzuata, Cumhurbaşkaninın genel siyasetine, Cumhurbaşkanı karar ve talimatlarına, kalkınma planlarina ve yıllik programlara uygun olarak yürütmekle, bakanlı̆̆ın faaliyet alanına giren konularda diğer bakanlıklarla işbirliği ve koordinasyonu sağlamakla görevli ve Cumhurbaşkanına karşı sorumludur" ifadesine çok da uyumlu görünmeyen şekilde, çok çeşitli kavramlar misyon ve vizyon ifadelerinde kendilerine yer bulduğu görülmüştür.

\section{SONUÇ ve DEĞERLENDİRME}

Araştırmada, Türkiye'de Kasım 2019 itibariyle kamu görevlerini yürütmek üzere oluşturulan 16 Bakanlığın misyon ve vizyon ifadeleri içerik analizi yöntemi ile incelenmiştir. Bu kavramların, Bakanlıkların işleyişine yönelik mevzuatta yer alan kavramlarla uyumlu olup olmadığı, uyumlu olmayan kavramlardan hangilerinin öne çıktığı ve öne çıkan bu kavramların sık kullanılmasının nedenleri belirlenmeye çalışılmıştır.

Bakanlıkların, kuruldukları Cumhurbaşkanlığı Kararnamesi içeriğinde kamu kaynaklarının kullanımı ile ilgili olarak vurgulanan kavramları vizyon ifadelerinde "hiç" tercih etmedikleri, misyon ifadelerinde ise "oldukça az" kullanmayı tercih ettikleri görülmüştür. Bu durumun "amaç birliği”ne gölge düşürebileceği ve kamu hizmetlerinin "yeknesaklığı"na zarar verebileceği değerlendirilebilir. Benzer uyumsuzluk, Ocak, Güler ve Basım (2016) tarafından savunma sanayi firmalarının misyon ve vizyon ifadelerinin içeriklerinin incelendiği çalışmada da görülmüştür. $\mathrm{Bu}$ çalışmaya göre, Türkiye'deki savunma sanayi firmalarının halen gelişmekte olan savunma sanayi ile uyumlu etkili misyon ve vizyon ifadeleri ile bütünleşik bir savunma sistemine sahip olmanın öneminin kavranamadığının göstergesi olarak değerlendirilmiştir (Ocak vd., 2016: 514).

İlgili mevzuatta geçen etkili, ekonomik ve verimli kavramları haricinde en çok kullanılan kavramlar kullanım sıklığına göre; "sürdürülebilirlik" (7), "yenilikçilik" (5), "güçlülük" (5), "kalkınmacılık" (4), "etkinlik" (4), "güvenli" (4), "katılımcılık" (3), “öncülük” (3) ve "erişilebilirlik" (3) olarak sıralanmıştır. Bu kavramların Bakanlıkların faaliyet alanlarına göre çeşitlendiği değerlendirilmektedir. Sürdürülebilirlik gibi kavramlar daha geniş bir anlam taşıdığ 1 için daha genel geçer bir ifadeyken, 
Tablo 3: Bakanlıkların Vizyon İfadelerinde Geçen Kavramların Dökümü

\begin{tabular}{|c|c|c|c|c|c|c|c|c|c|c|c|c|c|c|c|c|c|c|}
\hline \multirow[b]{2}{*}{ 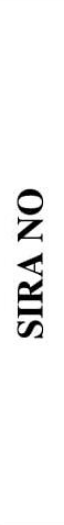 } & \multirow[b]{2}{*}{ 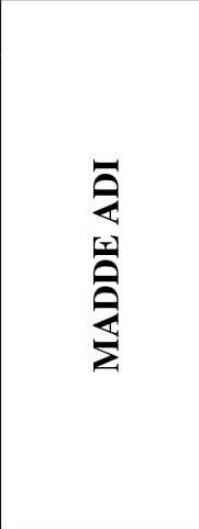 } & \multicolumn{16}{|c|}{ BAKANLIKLAR } & \\
\hline & & 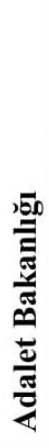 & 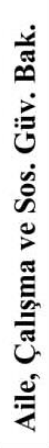 & 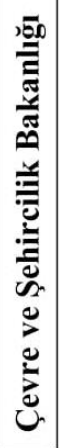 & 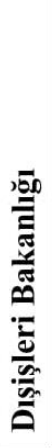 & 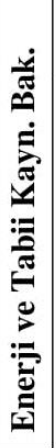 & 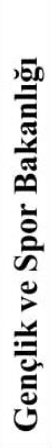 & 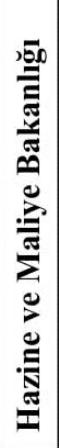 & 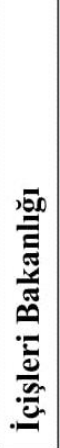 & 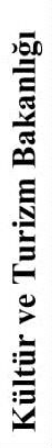 & 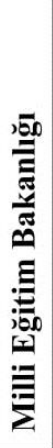 & 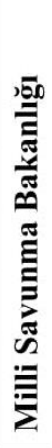 & 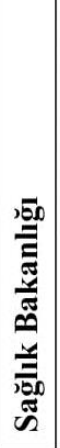 & 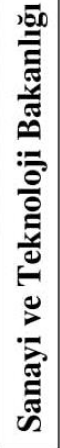 & 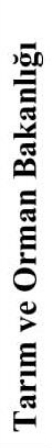 & 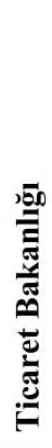 & 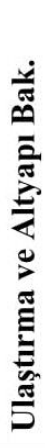 & $\sum_{0}^{\sum}$ \\
\hline 1 & Güçlülük & & $\mathbf{X}$ & & $\mathbf{X}$ & & & & & $\mathbf{X}$ & & & & $\mathbf{X}$ & $\mathbf{X}$ & & & 5 \\
\hline 2 & Güvenli & $\mathbf{X}$ & & & $\mathbf{X}$ & $\mathbf{X}$ & & & & & & & & & & & $\mathbf{X}$ & 4 \\
\hline 3 & Öncülük & & & & & & $\mathbf{X}$ & & & & & & & $\mathbf{X}$ & & $\mathbf{X}$ & & 3 \\
\hline 4 & Erişilebilirlik & $\mathbf{X}$ & & & & & & & & & & & $\mathbf{X}$ & & & & $\mathbf{X}$ & 3 \\
\hline 5 & Liderlik & & & & & & & & & $\mathbf{X}$ & & & & & & $\mathbf{X}$ & & 2 \\
\hline 6 & Rekabetçilik & & & & & & & & & & & & & & $\mathbf{X}$ & $\mathbf{X}$ & & 2 \\
\hline 7 & Millilik & & & & & & & & & & & $\mathbf{X}$ & & & $\mathbf{X}$ & & & 2 \\
\hline 8 & Üretkenlik & & $\mathbf{X}$ & & & & & & & & & & & & $\mathbf{X}$ & & & 2 \\
\hline 9 & Etkinlik & $\mathbf{X}$ & & & & & & & & & & $\mathbf{X}$ & & & & & & 2 \\
\hline 10 & Girişimcilik & & & & $\mathbf{X}$ & & & & & & & & & & & & & 1 \\
\hline 11 & Katılımcılık & & & & & & & $\mathbf{X}$ & & & & & & & & & & 1 \\
\hline 12 & Saygınlık & & & & & & & & & $\mathbf{X}$ & & & & & & & & 1 \\
\hline 13 & Küresellik & & & & & & & & & & & & & & $\mathbf{X}$ & & & 1 \\
\hline 14 & Öncülük & & & & & & & & & & & & & & & $\mathbf{X}$ & & 1 \\
\hline 15 & Süreklilik & & & & & & & & & & & $\mathbf{X}$ & & & & & & 1 \\
\hline 16 & Yenilikçilik & & & & & & & & & & & $\mathbf{X}$ & & & & & & 1 \\
\hline 17 & Evrensellik & & & & & & $\mathbf{X}$ & & & & & & & & & & & 1 \\
\hline
\end{tabular}

savunma sanayinde erişilebilirlik önemli olmayabilmektedir ya da öncülük her alana uyarlanamayabilmektedir. Bu nedenle Bakanlıkların çalışma alanlarının farklılığının misyon ve vizyon ifadelerindeki kavramları çeşitlendirdiği kanaatine varılmıştır.

Ayrıca, Gençlik ve Spor Bakanlığının misyon ve vizyon ifadelerini onay için Cumhurbaşkanlığına gönderdiğini ifade etmesi, ancak diğer 15 Bakanlığın web sitelerinde misyon ve vizyon ifadelerine ulaş1labilmesi, misyon ve vizyon ifadelerinin düzenlenmesinde zamana bağlı kalınmaksızın Bakanlıkların tekliflerinin değerlendirilmeye alındığını göstermesi bakımından önemlidir.

Acar (2003: 12) kamu kurumlarında stratejik yönetimin gerekliliğine uygun şekilde hareket edilmesinin etkili ve verimli bir yönetim şekli oluşturacağına vurgu yapmıştır. Dolayısıyla, etkili ve verimli olmanın stratejik yönetim sürecinin doğal bir sonucu gibi görülebileceğini belirtmiştir.

Sonuç olarak, Bakanlıkların bu kadar farklı kavramı, dağınık bir yaklaşımla misyon ve vizyon gibi önemli kurumsal ifadelerde kullanmalarının, kamu kurumları gibi aynı amaca hizmet eden resmi devlet kurumlarının amaç birliğine zarar verebileceği değerlendirilmektedir. Ayrıca, Bakanlıkların kuruluşunun düzenlendiğine benzer şekilde, yeni bir Cumhurbaşkanlığ Kararnamesi ile misyon vizyon ifadelerinde olmazsa olmaz nitelikteki ortak temel kavramların belirlenmesi ve bu kavramları kullanmanın zorunlu olacak şekilde ilgili Bakanlığın veya Bakanlığın emrindeki icracı makamların faaliyet alanına özgü özel kavramların kullanımı Bakanlıklara bırakılacak şekilde bir düzenleme yapılmasının faydalı olabileceği değerlendirilmektedir. 
Tablo 4: Bakanlıkların Misyon İfadelerinde Geçen Kavramların Dökümü

\begin{tabular}{|c|c|c|c|c|c|c|c|c|c|c|c|c|c|c|c|c|c|c|}
\hline \multirow[b]{2}{*}{ 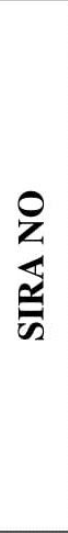 } & \multirow[b]{2}{*}{ 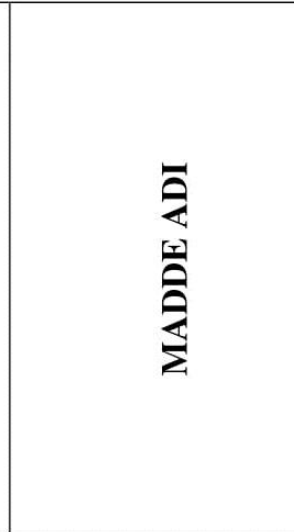 } & \multicolumn{16}{|c|}{ BAKANLIKLAR } & \multirow[b]{2}{*}{ 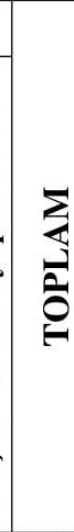 } \\
\hline & & 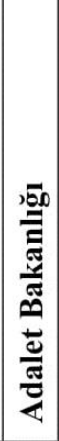 & 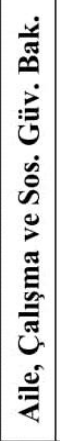 & 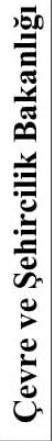 & 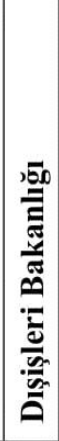 & 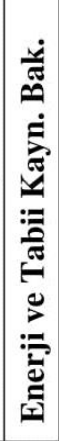 & 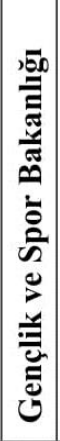 & 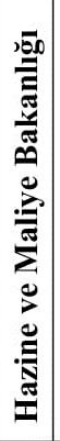 & 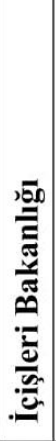 & 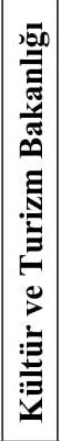 & 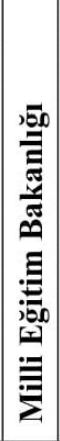 & 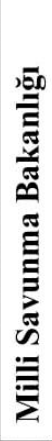 & 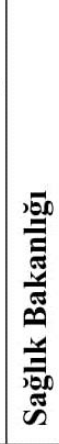 & 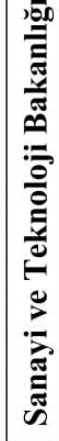 & 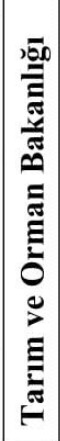 & 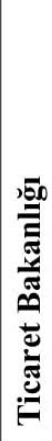 & 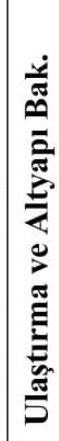 & \\
\hline 1 & Sürdürülebilirlik & & $\mathrm{X}$ & $\mathrm{X}$ & & & & $X$ & & $X$ & & & & $\mathrm{X}$ & $\mathrm{X}$ & $X$ & & 7 \\
\hline 2 & Yenilikçi & & & & & & $\mathrm{X}$ & $X$ & & & $X$ & & & & $X$ & $X$ & & 5 \\
\hline 3 & Etkinlik & & $\mathrm{X}$ & & & & & $\mathrm{X}$ & $X$ & & $\mathrm{X}$ & & & & & & & 4 \\
\hline 4 & Kalkınmacılık & & $X$ & & & & & $X$ & & & & & & & $X$ & & $X$ & 4 \\
\hline 5 & Katılımcılık & & & $\mathrm{X}$ & & & & $\mathrm{X}$ & & & & & & & & $\mathrm{X}$ & & 3 \\
\hline 6 & Etkililik & $X$ & & & & & & & $X$ & & & & $X$ & & & & & 3 \\
\hline 7 & Denetleyicilik & & $\mathrm{X}$ & $\mathrm{X}$ & & & & & & & & & & & & & & 2 \\
\hline 8 & Girișimcilik & & & & $\mathrm{X}$ & & & & & & $\mathrm{X}$ & & & & & & & 2 \\
\hline 9 & Çözüm Odaklılık & & & $\mathrm{X}$ & & & & & & & & & $\mathrm{X}$ & & & & & 2 \\
\hline 10 & Ekonomik & & $X$ & & & & & & & & & & & & & & $X$ & 2 \\
\hline 11 & Rekabetçilik & & & & & & $\mathrm{X}$ & & & & & & & $\mathrm{X}$ & & & & 2 \\
\hline 12 & Düzenleyicilik & & $\mathrm{X}$ & $\mathrm{X}$ & & & & & & & & & & & & & & 2 \\
\hline 13 & Çevreye Duyarlı & & & $\mathrm{X}$ & & $X$ & & & & & & & & & & & & 2 \\
\hline 14 & Erişilebilirlik & & & & & & & & & $\mathrm{X}$ & & & & & & & $\mathrm{X}$ & 2 \\
\hline 15 & Verimlilik & & & & & $X$ & & & & & & & & & & & & 1 \\
\hline 16 & Küresellik & & & & & & $\mathrm{X}$ & & & & & & & & & & & 1 \\
\hline 17 & Öncülük & & & & & & & $X$ & & & & & & & & & & 1 \\
\hline 18 & Hesap Verebilirlik & & & & & & & $X$ & & & & & & & & & & 1 \\
\hline 19 & Saydamlık & & & & & & & $X$ & & & & & & & & & & 1 \\
\hline 20 & Evrensellik & & & & & & & & & $X$ & & & & & & & & 1 \\
\hline
\end{tabular}

kamu kaynaklarını nasıl kullanması gerektiği açıklanırken kullanılan kavramlardır.

Kamu kurumlarının misyon ve vizyon ifadelerinin belirlenmesinde veya değerlendirilmesinde görev yapabilecek bir üst komisyonun oluşturulması ya da kamu kurumlarında misyon ve vizyon belirleme çalışmalarında görev alan kişilerin/komisyonların ortak bir eğitimden geçmelerinin mümkün olup olmadığı üzerine çalışmalar yapılması düşünülebilir. Ayrıca, kamu kurumlarında misyon ve vizyon ifadelerinde kesinlikle yer almasi gereken kavramların belirlenmesi ile ilgili uzmanların ortak akılla yürüttüğü çalışmalar da yapılabilir.
Bakanlıkların faaliyet alanlarına göre anahtar misyon ve vizyon ifadelerinin belirlenmesine yönelik, belirli özellikteki alanlara (sağlık, spor vb.) yönelik derinleştirilmiş çalışmalar yapılabilir. Ayrıca gelecekte, kamu kurumlarının misyon ve vizyon ifadelerinde anlam birliği sağlamak amaciyla bir kavram havuzu oluşturulmasına yönelik çalışmalar da yapılabilir. 


\section{ETIKK BEYANATI}

Destek Bilgisi: Bu çalışmada herhangi bir özel veya resmi bir kuruluştan ya da başka bir organizasyondan destek alınmamıştır.

Çıkar Çatışması: Tüm yazarlar adına, sorumlu yazar çıkar çatışması olmadığını belirtir.

Etik Onayı: $\mathrm{Bu}$ çalışmada gerçekleştirilen tüm prosedürler, kurumsal ve / veya ulusal araștırma komitesinin etik standartlarına ve 1964 Helsinki deklarasyonuna ve daha sonraki değişikliklerine veya karşılaştırılabilir etik standartlara uygundur.

\section{KAYNAKÇA}

Acar, A. (2003). Stratejik Yönetim ve Kamuda Uygulanan Stratejiler. Sosyal Ekonomik Araştırmalar Dergisi, 3(6), 1-15.

Altunışık, R., Coşkun, R., Bayraktaroğlu, S. \& Yıldırım, E. (2012). Sosyal Bilimlerde Araştırma Yöntemleri SPSS Uygulamalı (7. Bask1). Sakarya: Sakarya Yayınc1lı.

Ay, Ü. \& Koca, A. İ. (2012). ISO 500 İşletmelerinin Misyon, Vizyon ve Değerlerinin İçerik Analizi. Organizasyon ve Yönetim Bilimleri Dergisi, 4(2), 201-210.

Doğan, S. (2007). Vizyona Dayalı Liderlik (2. Baskı). İstanbul: Kare Yayınları.

Erçelik, M. A. (2014). Kamu Kurumlarında Stratejik Plan Üzerine Karşılaştırmalı Bir Inceleme (Yayımlanmamış Yüksek Lisans Tezi). Yüzüncü Y1l Üniversitesi Sosyal Bilimler Enstitüsü, Van.

Erdem, A. (2006). Stratejik Yönetim ve Kamu Örgütlerine Uygulanabilirliği (Yayımlanmamış Yüksek Lisans Tezi). Mersin Üniversitesi Sosyal Bilimler Enstitüsü, Mersin.

Gliner, J. A., Morgan, G. A. \& Leech, N. L. (2015). Uygulamada Araştırma Yöntemleri Desen ve Analizi Bütünleştiren Yaklaşım (2. Basımdan Çeviri, Çeviri Editörü S. Turan). Ankara: Nobel Akademik Yayıncilık.

Gözler, K. \& Kaplan, G. (2018). Kısa İdare Hukuku (12. Baskı). Bursa: Ekin Basım Yayın Dağıtım.

Gürbüz, S. \& Şahin, F. (2018). Sosyal Bilimlerde Araştırma Yöntemleri (5. Baskı). Ankara: Seçkin Yayıncilık.

Kunt, Ş. (2012). Türkiye'de Üniversitelerin Stratejik Planlarındaki Misyon, Vizyon ve Stratejik Amaçların İçerik Analizi (Yayımlanmamış Yüksek Lisans Tezi). Çukurova Üniversitesi Sosyal Bilimler Enstitüsü, Adana.

Nakip, M. \& Yaraş, E. (2017). Pazarlamada Araştırma Teknikleri ve SPSS Uygulamalar (4. Baskı). Ankara: Seçkin Yayıncılık.

Ocak, M., Güler, M. \& Basım, H. N. (2016). Türk Savunma Sanayi Firmaları Vizyon ve Misyon İfadelerinin İçerik Analizi. Yönetim ve Ekonomi: Celal Bayar Üniversitesi Iktisadi ve İdari Bilimler Fakültesi Dergisi, 23(2), 503-518.

Quigley, J. V. (1998). Vizyon Oluşturulması, Geliştirilmesi ve Korunmast. İstanbul: Epsilon Yayıncilık. 
Saruhan, Ş. C. \& Özdemirci, A. (2011). Bilim, Felsefe ve Metodoloji (2. Baskı). İstanbul: Beta Basım Yayım Dağıtım.

Taş, M. A., Çiçek, H. \& Yastığlu, S. (2019). Misyon, Vizyon ve Amaçlar bağlamında Geleceğe Bakıș: Mehmet Akif Ersoy Üniversitesi Stratejik Plan Çalışmaları Örneği. Mehmet Akif Ersoy Üniversitesi İktisadi ve İdari Bilimler Fakültesi Dergisi, 6(2), 544562.

Turan, A. M. (2018). Türkiye'nin Yeni Yönetim Düzeni: Cumhurbaşkanlığı Hükümet Sistemi. Social Sciences Research Journal, 7(3), 42-91.

Türkiye Cumhuriyeti Adalet Bakanlığı (2019, 30 Ekim). Erişim adresi http://www.adalet.gov.tr/Bakanlik/StratejikPlan/

Türkiye Cumhuriyeti Aile, Çalışma ve Sosyal Hizmetler Bakanlığı (2019, 30 Ekim). Erişim adresi https://ailevecalisma.gov.tr/bakanlik/hakkinda/misyon -ve-vizyonumuz

Türkiye Cumhuriyeti Çevre ve Şehircilik Bakanlı̆̆ı (2019, $30 \quad$ Ekim). Erişim adresi https://csb.gov.tr/misyon-vizyon-i-83459

Türkiye Cumhuriyeti Dışişleri Bakanlığ (2019, 30 Ekim). Erişim adresi http://www.mfa.gov.tr/data/BAKANLIK/2019-2023stratejik-plani.pdf

Türkiye Cumhuriyeti Enerji ve Tabii Kaynaklar Bakanlığı (2019, $30 \quad$ Ekim). Erişim adresi https://www.enerji.gov.tr/tr-TR/Sayfalar/MisyonVizyon

Türkiye Cumhuriyeti Gençlik ve Spor Bakanlığı (2019, $01 \quad$ Kasım). $\quad$ Erişim adresi http://www.gsb.gov.tr/public/edit/files/strateji/faaliyet -raporu-2018-090819.pdf

Türkiye Cumhuriyeti Hazine ve Maliye Bakanlığı (2019, 30 Ekim). Erişim adresi https://ms.hmb.gov.tr/uploads/2018/10/MaliyeBakanl\%C4\%B1\%C4\%9F\%C4\%B1-2018-2022Stratejik-Plan\%C4\%B1.pdf

Türkiye Cumhuriyeti İçişleri Bakanlığı (2019, 30 Ekim). Erişim adresi https://www.icisleri.gov.tr/hakkimizda

Türkiye Cumhuriyeti Kültür ve Turizm Bakanlığı (2019, 30 Ekim). Erişim adresi https://www.ktb.gov.tr/TR133260/misyonumuz-vizyonumuz.html

Türkiye Cumhuriyeti Millî Eğitim Bakanlığı (2019, 30 Ekim). Erişim adresi http://www.meb.gov.tr/vizyonmisyon/duyuru/8851

Türkiye Cumhuriyeti Millî Savunma Bakanlığ $(2019,30$ Ekim). Erişim adresi https://msb.gov.tr/Bakanlik/Misyon
Türkiye Cumhuriyeti Sağlık Bakanlığı (2019, 30 Ekim). Erişim adresi https://www.saglik.gov.tr/TR,11465/kurumsalpolitikalarimiz.html

Türkiye Cumhuriyeti Sanayi ve Teknoloji Bakanlığı (2019, $01 \quad$ Kasım). Erişim adresi https://strateji.sanayi.gov.tr/Handlers/DokumanGetHa ndler.ashx?dokumanId=0281e410-aebd-42a5-8d8108540b3f2776

Türkiye Cumhuriyeti Tarım ve Orman Bakanlığı (2019, 30 Ekim). Erişim adresi https://www.tarimorman.gov.tr/SGB/Belgeler/strateji kplan.pdf

Türkiye Cumhuriyeti Ticaret Bakanlığı (2019, 30 Ekim). Erişim adresi https://ticaret.gov.tr/data/5b921d6513b87613646656a c/Stratejik_Plan_2018_2022.pdf

Türkiye Cumhuriyeti Ulaştırma ve Altyapı Bakanlığı (2019, $30 \quad$ Ekim). Erişim adresi https://www.uab.gov.tr/uploads/pages/stratejikyonetim/uab-2019-2023-stratejik-plani-16-102019.pdf

Uçar, N. M. (2010). Stratejik Yönetim ve Kamu Sektörü Uygulamalarına Yönelik Bir Araştırma (Yayımlanmamış Yüksek Lisans Tezi). Atılım Üniversitesi Sosyal Bilimler Enstitüsü, Ankara.

Ülgen, H. \& Mirze, S. K. (2018). İşletmelerde Stratejik Yönetim (9. Baskı). İstanbul: Beta Basım Yayım Dağıtım A.Ş.

Yıldırım, A. \& Şimşek, H. (2006). Sosyal Bilimlerde Nitel Araştırma Yöntemleri (6. Baskı). Ankara: Seçkin Yayıncilık. 